\title{
„MIEĆ SUKCES W PARYŻU!”1 KOSSAKOWIE OJCIEC I SYN PODBIJAJĄ PARYŻ
}

\author{
Ewa BOBROWSKA (Paryż) \\ ORCID: 0000-0002-2909-4800
}

Już od końca XVIII wieku Paryż, zanim stał się światową stolicą sztuki, był celem wędrówek, nie zawsze dobrowolnych, Polaków. Znajdowali tam schronienie uchodźcy po kolejnych, zakończonych klęską zrywach niepodległościowych. Udział Polaków walczących w szeregach Wielkiej Armii z nadzieją, że wybiją się w ten sposób na niepodległość, związał na długo zbiorową pamięć i wyobraźnię Polaków z Francją, a w szczególności jej stolicą. Paryż był gościnny dla Wielkiej Emigracji, przynajmniej w mniemaniu jej członków, pozwalając jej stworzyć i rozwinąć struktury i instytucje o charakterze narodowym, jak Biblioteka Polska, Szkoła Narodowa Polska, Polska Misja Katolicka, towarzystwa o charakterze naukowym, kulturalnym i społecznym. W sytuacji ograniczeń wolności narodowych i politycznych na własnej ziemi pod zaborami, Paryż, dzięki iluzji swobodnego przeżywania czy wręcz egzaltacji własnej tożsamości narodowej, zasłużył nawet na miano drugiej stolicy Polski ${ }^{2}$. W tym samym okresie stolica Francji nabierała rangi ważnego ośrodka artystycznego na skalę światową. Prezentacja dzieł w Paryżu, a zwłaszcza na dorocznym Salonie, stawała się synonimem nobilitacji i sukcesu nie tylko dla twórców francuskich, ale także zagranicznych. Było więc zupełnie naturalne, że udawali się tam również polscy artyści. Jedni, jak Teofil Kwiatkowski, Karol (Charles) Malankiewicz czy Piotr Michałowski, znaleźli się tam z przyczyn politycznych, na fali Wielkiej Emigracji, jako uchodźcy po klęsce powstania listopadowego. Inni, jak Antoni Oleszczyński, Henryk Rodakowski czy Leon Kapliński, jechali tam z przyczyn artystycznych, by poznać nowe tendencje w sztuce, doskonalić swój talent pod okiem francuskich mistrzów czy też poszukiwać sławy. Sukcesy Rodakowskiego czy Matejki odnoszone we francuskiej stolicy, często wyolbrzymione przez polską prasę, działały na wyobraźnię pozbawionych swobodnych

${ }^{1}$ W. Kossak, Listy do żony i przyjaciót (1883-1942), t. 2, oprac. K. Olszański, Kraków 1985, s. 315.

${ }_{2}^{2}$ Por. np. Polonia. Des Polonais en France de 1830 à nos jours, red. J. Ponty, Paris 2011. 
możliwości rozwoju artystycznego twórców w kraju i zachęcały ich do podjęcia paryskiego wyzwania. Paryż fascynował tempem życia i wielkomiejskim rozmachem, zwłaszcza w okresie II cesarstwa, kiedy miasto zaczęło się dynamicznie rozwijać i unowocześniać. Bez względu na zmieniające się we Francji reżimy polityczne, pro- czy antynapoleońskie, legenda cesarska $\mathrm{w}$ mieście, które przyjęło jego zwłoki z wielką pompą ${ }^{3} \mathrm{w}$ jednej z kaplic Inwalidów w 1840 roku, a w 1861 roku pod kopułę kościoła Świętego Ludwika, była wciąż żywa. W Hôtel des Invalides mieszkali jeszcze weterani Wielkiej Armii i spotkać ich można było na Esplanadzie. Nieco dalej, w okolicach Ecole Militaire, odbywały się wojskowe ćwiczenia i parady. Obrazy francuskich artystów o tematyce związanej z Wielką Wojną były obecne w stolicy. Polacy przebywający w tym mieście oddychali na co dzień atmosferą patriotyczno-wojskową, co nie mogło pozostać bez wpływu na ich własną twórczość.

Urodzony w 1824 roku Juliusz Kossak przybył do Paryża po raz pierwszy na przełomie 1852 i 1853 roku. Miał wtedy za sobą pierwsze zetknięcie z wielkim malarstwem europejskim w latach 1849-1851 w Petersburgu, a następnie w 1852 roku w Wiedniu. Uprawiał już wówczas swobodnie zawód artysty. Po ślubie z Zofią z Gałczyńskich wyjechał do Paryża w 1855 roku dzięki pomocy finansowej teścia. Przebywał tam wraz z żoną przez pięć lat. Tam też powiększyła mu się rodzina o synów Wojciecha i Tadeusza. W Paryżu przyjaźnił się ze znacznie młodszym od siebie Józefem Brandtem, a także Henrykiem Rodakowskim ${ }^{4}$ i Leonem Kaplińskim. Poznał również francuskiego malarza Horace'a Verneta, słynnego z malarstwa scen bitewnych, sportowych i orientalistycznych, którego twórczość wywarła pewien wpływ na jego sztukę 5 . Za ucznia Verneta uważał go Paul Guinard ${ }^{6}$, zapewne choćby na podstawie informacji zamieszczonej przy nazwisku artysty w katalogu Salonu w 1878 roku? $^{7}$.

W Paryżu Juliusz zwiedzał kolekcje dzieł sztuki. W Luwrze kopiował obrazy Géricaulta, Ruysdaela, Rubensa i Troyona. Zetknął się nie tylko z wielkim malarstwem francuskiego romantyzmu, ale także zapewne z dziełami będącymi przykładami „sztuki francusko-polskiej, związanej z emigracją" (art franco-polonais de l'émigration). Były to prace nawiązujące do wydarzeń $\mathrm{z}$ najnowszej historii relacji francuskopolskich, bogate w polską ikonografię, o charakterze głównie militarnym, które zaczęły powstawać wraz z przybyciem do Francji uchodźców polskich po klęsce powstania listopadowego. Jednym z koronnych przykładów może być Prometeusz polski Hora-

\footnotetext{
${ }^{3}$ Por. opis pogrzebu Napoleona pióra Victora Hugo, Euvres complètes, t. 25, Paris 1913, s. $39-58$.

${ }^{4}$ Pięknym plastycznie świadectwem tej przyjaźni jest akwarela Juliusza, przedstawiająca paryską pracownię Rodakowskiego z 1857 r., ze zbiorów Muzeum Narodowego w Warszawie.

${ }^{5}$ L. Réaux, L'art français en Pologne au XIXe siècle, Revue des Études Slaves 1923 t. 3, fasc. $1-2$, s. 125.

${ }^{6} \mathrm{P}$. Guinard, Les thèmes polonais dans l'art français du XIXe siècle, [w:] C. FilipowiczOsieczkowska, P. David, P. Guinard, A.-J. Lauterbach, W. Tatarkiewicz, Art polonais art français: Études d'influences, Paris 1939, s. 99.

${ }^{7}$ Explication des ouvrages de peinture et dessins, sculpture, architecture et gravure et lithographie des artistes vivants exposés au Palais des Champs-Elysées, Paris 1878, s. 280. Możemy się domyślać, że to Wojciech zadbał o wstawienie prac ojca na Salon w $1878 \mathrm{r}$., gdzie sam również wystawiał. To zapewne też Wojciech sformułował tekst, jaki widniał w katalogu obok nazwiska Juliusza. Ponieważ Wojciech podawał się za ucznia swojego ojca, mogło mu zależeć na tym, żeby podkreślić, że ojciec z kolei był wychowankiem znanego francuskiego mistrza.

${ }^{8} \mathrm{P}$. Guinard, Les thèmes polonais, s. 96.
} 
ce'a Verneta (ok. 1831) ${ }^{9}$. Tworzono je jeszcze w okresie II cesarstwa. Juliusz miał także okazję rysować konie z natury. Obserwował je w ujeżdżalniach, rzeźniach i na musztrach wojskowych. Jak wspomina Wojciech Kossak, jego ojciec bywał w Paryżu w kręgach polskiej emigracji politycznej i wojskowej. Znał księcia Adama Jerzego Czartoryskiego, generałów Dembińskiego i Zamoyskiego, pułkowników Michała Mycielskiego, Wysockiego i wielu innych oficerów, weteranów wojen napoleońskich. Ich opowieści naznaczyły pamięć artysty i jego wyobraźnię twórczą ${ }^{10}$. Mieszkając niedaleko Pałacu Inwalidów, mógł obserwować to, co pozostało z cesarskiego „snu o potędze”, m.in. tragiczne w swej wymowie pochody jego lokatorów - garstki weteranów ubranych w znoszone, połatane, acz odświętne mundury — na Plac Vendôme. Rokrocznie świętowali oni w ten sposób imieniny ukochanego wodza ${ }^{11}$. Na Placu Vendôme, pod brązową kolumną odlaną z dział zdobytych przez Napoleona na wojskach rosyjskich i austriackich, zdobioną płaskorzeźbami przedstawiającymi sceny bitewne i trofea wojskowe, wpatrzeni w wieńczącą ją statuę „Małego Sierżanta”, zdawali się oczekiwać jego kolejnego rozkazu.

Dzięki tak wszechstronnej stymulacji talent Juliusza widocznie rozwinął się w okresie jego pobytu w Paryżu, a dzieła, które tam stworzył, m.in. Polowanie w Poturzycy, Przeprawa przez Dniestr, Stadnina Mohorta, ,posiadały już wartość w skali sztuki europejskiej, widać w nich dojrzałość w opanowaniu rzemiosła i plastyczność postaci osiąganą za pomocą światłocienia, w całości poetycki, idealizujący nastrój, w odróżnieniu od dawniejszych, nieco suchych i pedantycznych kompozycji”' ${ }^{12}$. Na Salonie w 1857 roku $^{13}$ pokazał akwarelę zatytułowaną Haras ukrainien à l'abrevoir (Stado u wodopoju). Zwróciła ona uwagę krytyka Edmonda Abouta jako dobre studium z natury ${ }^{14}$. Artysta nie czuł się jeszcze wówczas stuprocentowym Paryżaninem i w katalogu Salonu podawał zarówno swój adres warszawski, jak i paryski, przy ulicy Vanneau 39. Na Salonie w 1859 roku malarz, już wyłącznie jako Paryżanin, wystawił z kolei dwie prace, Les cosaques en marche (nr 1677) oraz Morsztyn: chevalier polonais du temps de Sigismond III, faisant prisonnier un chef tartare $(\mathrm{nr} 1678)^{15}$.

Siedem lat po powrocie do Warszawy Juliusz odwiedził Paryż raz jeszcze, by obejrzeć Wystawę Światową w 1867 roku. W ramach ekspozycji rosyjskiej pokazane tam były wówczas jego dwie akwarele: Le marché aux chevaux à Praga, faubourg de Varsovie oraz Cosaques en marche ${ }^{16}$. W 1878 roku z kolei na Salonie wystawione zostały

${ }^{9}$ H. Vernet, Alegoria Polski zwyciężonej albo Prometeusz polski, ok. 1831, Biblioteka Polska w Paryżu.

${ }^{10}$ W. Kossak, Wspomnienia, Warszawa-Lublin-Łódź-Kraków 1913, s. 6-14.

${ }^{11}$ Tamże, s. 14-15.

${ }^{12}$ Kossakowie, przewodnik po wystawie, red. Z. Żygulski jun., Muzeum Narodowe w Krakowie, Kraków 1986, s. 12.

${ }^{13}$ Explication des ouvrages de peinture et dessins, sculpture, architecture et gravure et lithographie des artistes vivants exposés au Palais des Champs-Elysées, Paris 1857, s. 187, nr 1486.

${ }^{14}$ E. About, Nos artistes au Salon de 1857, Paris 1858, s. 351. Krytyk wymienia ją pod skróconym tytułem Chevaux d'Ukraine (Konie ukraińskie).

${ }^{15}$ Explication des ouvrages de peinture et dessins, sculpture, architecture et gravure et lithographie des artistes vivants exposés au Palais des Champs-Elysées, Paris 1859, s. 205, nr 1678.

${ }^{16}$ Exposition Universelle de 1867 à Paris Catalogue général publié par la Commission Impériale le livraison: oeuvres d'art Groupe I Classes, 1 à 5, Paris-London 1967. 
jeszcze inne jego akwarele ${ }^{17} \mathrm{z}$ kolekcji prywatnych: Election du roi Jean-Casimir, en 1648 (nr 3210) oraz Les comtes Jynkiewiz (sic !), Wasyl et Juryc passent la Dniepr en conduisant leurs regiments de cavalerie ... les Russes, 1651 (nr 3211). Jego dwie pra$\mathrm{ce}^{18}$ znalazły się także pośmiertnie na reprezentacyjnej wystawie sztuki polskiej w Paryżu w 1921 roku.

Wojciech urodził się w Paryżu w noc sylwestrową 1856/1857. Był bardzo dumny, że jego ojcem chrzestnym był malarz Horace Vernet. Porównywał trzy pokolenia Kossaków: Juliusza, siebie i swego syna Jerzego, do malarskiej dynastii Vernetów: ClaudeJosepha, Carle'a i Horace'a ${ }^{19}$. Jak wspomniałam, rodzina Kossaków mieszkała w niedalekim sąsiedztwie Pałacu Inwalidów, gdzie dożywali swoich dni weterani wojen napoleońskich, często kalecy. Wojciech miał okazję widywać ich w dzieciństwie, choćby w czasie codziennych spacerów z piastunką ${ }^{20}$. $Z$ jednej strony znoszone, ale owiane legendą mundury żołnierzy Wielkiej Armii, z drugiej zaś barwne i pyszne uniformy gwardii przybocznej Napoleona III musiały pozostawić w chłopięcym umyśle niezatarte ślady. Te dziecięce wizje i wspomnienia dorosły już artysta będzie przenosił z entuzjazmem na płótno.

W 1877 roku Wojciech znalazł się znów w Paryżu, by kontynuować studia, które odbywał wcześniej w Krakowie i w Monachium. Miał też za sobą roczną służbę wojskową. W Paryżu pozostał, podobnie jak jego ojciec Juliusz, pięć lat, od 1877 do 1883 roku. Artysta używał tam imienia Albert, będącego francuskim odpowiednikiem Wojciecha, dodając do niego drugie imię Horace, które nosił po ojcu chrzestnym. Do wyjazdu nakłonił go ojciec, który zapewnił mu opiekę w gościnnym domu swego przyjaciela, hr. Konstantego Branickiego, i jego żony Jadwigi z Potockich. Siedziba Branickich przy ulicy Penthièvre zastępowała już wtedy, pod koniec lat 70. XIX wieku, ognisko, które wcześniej dla Polaków stanowił Hôtel Lambert Czartoryskich. Od Henryka Rodakowskiego ojciec uzyskał dla Wojciecha list polecający do francuskiego malarza Leona Bonnata. Bonnat przyjął go do swojej szkoły przy Boulevard de Clichy. Wbrew dotychczasowym informacjom ${ }^{21}$ Wojciech nie mógł uczęszczać do jego pracowni w paryskiej Szkole Sztuk Pięknych, ponieważ Bonnat został mianowany tam profesorem kierownikiem pracowni dopiero w 1888 roku $^{22}$. Nie jest również pewne, czy Kossak w ogóle studiował w Ecole des Beaux-Arts ${ }^{23}$, czy to u Alexandre'a Cabanela, czy w jakiejkolwiek innej pracowni, ponieważ opublikowane listy studentów tej uczelni nie podają jego nazwiska ${ }^{24}$. Wspomnienia malarza przywołują stosunkowo mało szczegółów na temat jego paryskich studiów, za wyją̧kiem barwnego opisu przyjęcia go do grona uczniów Bonnata ${ }^{25}$. Bonnat był wówczas u szczytu sławy. Znany był zarówno ze

${ }^{17}$ Explication des ouvrages de peinture et dessins, sculpture, architecture et gravure et lithographie des artistes vivants exposés au Palais des Champs-Elysées, Paris 1878, s. 280.

${ }^{18}$ Catalogue de l'exposition d'art polonais au Salon de la Société Nationale des Beaux-Arts, Paris, 13 avril-30 juin 1921, s. 11, nr 73. Cosaque (Kozak) i 74. Traîneau (Sanie).

${ }^{19}$ W. Kossak, Wspomnienia, s. 4.

${ }^{20}$ Tamże.

${ }^{21}$ H. Kubaszewska, Wojciech Kossak, [w:] Stownik artystów polskich $i$ w Polsce dziatajacych (zmarlych przed 1966 r.). Malarze, rzeźbiarze, graficy, t. IV: Kl-La,Warszawa 1986, s. 142.

${ }_{22}^{2}$ Por. G. Saigne, Léon Bonnat, le portraitiste de la IIIe République, Paris 2017, s. 658.

${ }^{23}$ H. Kubaszewska, Wojciech Kossak, s. 142.

${ }^{24}$ Por. Archives de l'Ecole nationale supérieure des beaux-arts (AJ52 1 à 1415). Inventaire par Brigitte Labat-Poussin avec la collab. de Caroline Obert, Table générale des dossiers du personnel et des élèves, Centre historique des Archives nationales : la Documentation française, Paris 1998, s. 388.

${ }^{25}$ W. Kossak, Wspomnienia, s. 62-65. 
swoich scen religijnych, jak i historycznych, ale przede wszystkim portretów. Pozostawił ponad dwieście wizerunków znanych postaci, m.in. męża stanu Adolphe’a Thiersa (1877) oraz pisarza Victora Hugo (1879), czym zasłużył sobie na miano „portrecisty III Republiki”, wielokrotnie odznaczanego, m.in. Legią Honorową. To zapewne obracanie się w kręgach uznanych twórców akademickich wyrobiło w Wojciechu przekonanie o wybitnym poziomie sztuki francuskiej w tamtym okresie, z czym zresztą trudno się nie zgodzić. Spośród starszego pokolenia francuskich artystów Polak najbardziej cenił wziętych portrecistów, jak Carolus-Duran, Cabanel czy Bonnat. Wysoko stawiał malarstwo batalistów, „napoleonistów” Ernesta Meissoniera i Edouarda Détaille’a czy autora scen z wojny francusko-pruskiej Alphonse'a de Neuville'a. Do jego ulubionych twórców należeli malarze scen historycznych, religijnych i rodzajowych, jak: Mihály Munkácsy, Benjamin Constant Lefebvre, Pierre Puvis de Chavannes, William Bouguereau, Jean-Paul Laurens, Nélie Jacquemart, Henri Harpignies, a z młodszych Albert Besnard, Pascal Dagnan-Bouveret, Henri Gervex, François Flameng. Kossak widział jednak tylko jedną, oficjalną, ,akademicką” stronę francuskiej sceny artystycznej, nie dostrzegając głębokich przemian, jakie w niej zachodziły. Nowych tendencji w sztuce, takich jak impresjonizm, nie zauważał w ogóle, choć w czasie jego pobytu w stolicy Francji miało tam miejsce pięć wystaw impresjonistów (III-VII), a Théodore Duret opublikował w 1878 roku jedno z pierwszych studiów na temat tego kierunku: Les peintres impressionnistes Claude Monet, Sisley, C. Pissarro, Renoir, Berthe Morisot ${ }^{26}$. We Wspomnieniach Wojciecha na próżno szukać o tym najmniejszej choćby wzmianki. Także wiązana często ze środowiskiem impresjonistów i postimpresjonistów koncepcja artystycznej bohemy, biednych, przeklętych, umierających z głodu i gruźlicy twórców, była Wojciechowi zupełnie obca. Z pewnością nauka w pracowni Bonnata, a także powodzenie i splendory, jakie były udziałem jego ojca, musiały ukształtować u Wojciecha ideał artysty sławnego, odnoszącego sukcesy, także finansowe i towarzyskie, do którego będzie on później dążyć.

Malarz brał udział w życiu artystycznym francuskiej stolicy, m.in. wystawiając na Salonie w latach 1878-1880. Zadebiutowal Autoportretem w mundurze C.K. ułanów ${ }^{27}$, precyzując w katalogu, że jest wychowankiem Akademii monachijskiej oraz swojego ojca i Bonnata. Było to niewątpliwie świadomym aktem autoreklamy: obraz, przedstawiający przystojnego, młodego artystę w mundurze, a więc mającego za sobą służbę wojskową, a także wykształcenie akademickie, nauki u znanego polskiego batalisty oraz portrecisty słynnego $\mathrm{w}$ paryskim świecie, był widomym znakiem talentu jego autora w obu tych dziedzinach malarstwa. W 1879 roku Wojciech wystawił na Salonie Les manoeuvres militaries, en Galicie (Autriche) ${ }^{28}$, a w roku następnym Portret panny $D^{29}$. Ekspozycja tej pracy stała się przyczyną artystycznego skandalu, świadczącego

${ }^{26} \mathrm{~T}$. Duret, Les Peintres impressionnistes, Paris 1878.

${ }^{27}$ Explication des ouvrages de peinture et dessins, sculpture, architecture et gravure et lithographie des artistes vivants exposés au Palais des Champs-Elysées, Paris 1878, s. 109, nr 1265 - Kossak Albert-Horace, né à Paris, élève de l'Académie de Munich, de son père et de M. Bonnat - Avenue de Villiers 45, Portrait de l'auteur en uniforme de lancier autrichien.

${ }^{28}$ Explication des ouvrages de peinture et dessins, sculpture, architecture et gravure et lithographie des artistes vivants exposés au Palais des Champs-Elysées, Paris 1879, s. 141, nr 1699.

${ }^{29}$ Explication des ouvrages de peinture et dessins, sculpture, architecture et gravure et lithographie des artistes vivants exposés au Palais des Champs-Elysées, Paris 1880, s. 199, nr 2018. 
o temperamencie młodego artysty i jego poczuciu własnej wartości ${ }^{30}$. Panna Fifine, a właściwie Céline Delèsy, była młodą i bardzo ładną aktorką. Kossak, choć sceptyczny wobec jej talentu, uznał jednak, że jej popularność w paryskim światku będzie dla niego doskonałą reklamą i zaproponował jej wykonanie portretu en pied. Obraz był stosunkowo dużego formatu $(96 \times 57 \mathrm{~cm})$, namalowany w stylu Bonnata. Uroczysty wernisaż, na którym wówczas jeszcze rzeczywiście werniksowano prace malarskie, skupiał cały paryski „wielki świat”, w tym wielkich marszandów czy, jak ich artysta określał, protektorów sztuki, Goupila i Sedelmayera. Interesujące jest, kogo Kossak zaliczał do ówczesnych osobistości: Ferdinanda de Lessepsa, francuskiego dyplomatę i twórcę Kanału Sueskiego, kompozytora Charlesa Gounoda, aktorkę Sarah Bernardt, młodą rosyjską malarkę Marie Baszkircew, a także finansistów Rothschilda i Maurice’a Ephrussiego. Artysta i jego modelka długo poszukiwali portretu w Palais de l'Industrie przy Champs Elysées. Wreszcie znaleźli go w galerii zewnętrznej, gdzie padały nań promienie słońca, przechodzące przez różnokolorowy witraż i zmieniające całkowicie jego kolorystykę. Przyczyną tak niekorzystnego zawieszenia portretu była nadmierna liczba prac przyjętych na wystawę. Urażony do żywego artysta uznał, że jego dzieło zostało zniweczone i zbezczeszczone. Niewiele myśląc, pożyczył od werniksujących obrazy robotników nóż i drabinę i z iście ułańską fantazją wyciął obraz z ramy. Desperacki czyn spotkał się z aprobatą publiczności. Sprawą zainteresował się literat Aurélien Scholl ${ }^{31}$, który pomógł Kossakowi nagłośnić ją w prasie, co było dla młodego twórcy sporą reklamą. Epizod ten nie był jedynym wydarzeniem, świadczącym o krewkim temperamencie Kossaka, jaki ujawnił się w gorącej paryskiej atmosferze. Świadczy też o nim pojedynek, jaki artysta miał stoczyć w 1885 roku z hr. Jerzym Pusłowskim. Przyczyną zbrojnej konfrontacji był romans, jaki młody malarz miał z żoną hrabiego. Do walki na szczęście jednak nie doszło z powodu interwencji spowiednika hrabiego ${ }^{32}$.

Od czasu incydentu na Salonie Wojciech stał się osobą publiczną i mniej lub bardziej prawdziwe informacje na jego temat pojawiały się na łamach francuskiej prasy. W 1884 roku na przykład gazeta „L'Intransigeant” podała wiadomość o rzekomej śmierci malarza, „oficera ułanów gwardii austriackiej”, w pojedynku w okolicach Krakowa, przypominając przy okazji, że był on chrzestnym synem Horace'a Verneta i synem ,wielkiego akwarelisty" ${ }^{\text {,33. }}$.

Pod koniec stycznia 1890 roku malarz znów powrócił do Paryża, gdzie spędził około pół roku ${ }^{34}$. Wynajął pracownię pod nr. 50 rue Saint-Georges. Kossak obracał się w drogich mu kręgach arystokratycznych, m.in. Dolores i Dominika Radziwiłłów, a także brata Dominika, Konstantego i jego rodziny. Utrzymywał także kontakty z polską kolonią artystyczną, m.in. z malarzem Pawłem (Paul) Merwartem, który okazał się uczynnym i kompetentnym przewodnikiem po paryskim świecie sztuki, a także z Józefem Męciną Krzeszem. Od pewnego momentu korzystał także z pracowni Teodora Axentowicza, z którym był zaprzyjaźniony. Merwart namówił Kossaka do ponownego udziału w paryskim Salonie. Jury przedstawiono tym razem 7500 obrazów, z których przyjęto jednak tylko 2000 , czyli mniej niż jedną trzecią. Artysta pokazał tam jeden z epizodów Wielkiej Wojny, Wzięcie do niewoli Tyszkiewicza w odwrocie spod Mo-

${ }^{30}$ W. Kossak, Wspomnienia, s. 68-75.

${ }^{31}$ Aurélien Scholl (1833-1902), francuski dziennikarz i literat.

${ }^{32}$ W. Kossak, Listy do żony i przyjaciót (1883-1942), t. 1: lata 1883-1907, wybór, opracowanie, wstęp przypisy, indeksy K. Olszański, Kraków 1985, s. 133-134.

${ }^{33}$ L'Intransigeant nr 1625 z 25 grudnia 1884 r., s. 3.

${ }^{34}$ W. Kossak, Listy do żony i przyjaciót (1883-1942), t. 1, s. 161 i n. 
$s k w y^{35}$. Tym razem artysta był zadowolony z zawieszenia swojej pracy. Rezultaty udziału w Salonie były rozmaite. Royal Gallery wybrała jego obraz, wraz z setką innych, na wystawę w Londynie. Artysta spodziewał sie także medalu: „[...] Axentowicz, malarz portrecista, który teraz z Anglii wrócił i winszuje mi, że tam jadę, powiedział mi, że jak tylko bez protekcji powieszą obraz, tak jak mój powiesili, to une récompense est certaine ${ }^{, 36}$. Jednak zamiast medalu otrzymał jedynie wyróżnienie. Tłumaczył to sobie, prawdopodobnie słusznie, tym, że kryzys Salonu, jaki miał miejsce w 1890 roku i doprowadził do utworzenia dwóch odrębnych salonów, spowodowany był nadmierną liczbą medali i nagród przyznawanych artystom zagranicznym ${ }^{37}$. Wojciech ubolewał także nad brakiem odpowiednich znajomości wśród członków jury był w Paryżu obcy i nawet jego wizyta u byłego profesora, Leona Bonnata, w poszukiwaniu protekcji nie przyniosła oczekiwanych rezultatów. Zamiast medalu otrzymał francuskie Palmy akademickie, co było także powodem do dumy i znakomitym pretekstem do ugruntowania swojej pozycji w Polsce, gdzie każdy sukces paryski był skrupulatnie odnotowywany. Kossak doskonale zdawał sobie sprawę z wagi działań reklamowych i jak tylko ukazały się pierwsze pozytywne krytyki prasowe we Francji (np. w Le Monde Catholique), plasujące go w towarzystwie artystów akademickich, takich jak Jean-Georges Vibert czy Jean-Léon Gérôme, przesyłał je żonie z prośbą o przekazanie ich prasie polskiej. Spotykał się także z polskimi dziennikarzami, ,dyktując im korespondencje",38.

Poza spotkaniami towarzyskimi w świecie arystokratycznym atrakcją były dla niego wyjścia do teatru, a także oglądanie świeżo wzniesionej wieży Eiffla, „tak przejrzystej i leciutkiej jak koronka"39. Nie zaniedbywał też kontaktów w ambasadzie austriackiej. U księdza Zdzitowieckiego miał okazję zawrzeć znajomość z weteranami powstania listopadowego ${ }^{40}$. Poznał także innego uczestnika tego zrywu, mieszkającego we Francji kolekcjonera, Wiktora Osławskiego, i miał nadzieję na uplasowanie swoich dzieł w jego kolekcji. Kolonia polska wysoko ceniła pozycję Kossaka. Powierzyła mu m.in. rolę reprezentanta polskich artystów na uroczystościach związanych z przeniesieniem prochów Adama Mickiewicza na Wawel. Kossak wraz z Anną Bilińską (,,brzydką jak noc" ${ }^{\text {"1 }) ~ i ~ T e o d o r e m ~ A x e n t o w i c z e m ~ n i o ́ s ł ~ w i e n i e c ~ o d ~ a r t y s t o ́ w ~ w ~ c z a s i e ~ c e r e m o n i i ~}$ ekshumacji wieszcza na cmentarzu w Montmorency. Artysta odwiedzał również wystawy sztuki, w tym np. Salon akwarelistów, na którym zafrapowały go szczególnie prace młodych artystów francuskich: Maurice'a Bouteta de Monvela, Aimé Morota i Louisa Roberta Cuvillona. Wiele uwagi poświęcał oglądaniu malarstwa koni, podkre-

\footnotetext{
${ }^{35}$ Pod francuskim tytułem Le général comte Thadée Tyszkiewicz (Tyrskiewicz), est fait prisonier par les cosaques pendant la retraite de Moscou. Malarz wystawił wówczas również Portrait du petit prince L. R., czyli portret syna Konstantego Radziwiłła, Leona zwanego Lochem. Por. Salon de 1890. Catalogue illustré. Peinture, sculpturel publié sous la direction de F.-G. Dumas; L. Baschet (Paris) 1890, s. 23, nr 1315 i 1316.

${ }^{36}$ W. Kossak, Listy do żony i przyjaciót (1883-1942), t. 1, s. 184.

${ }^{37}$ O kulisach tego kryzysu i rozłamie Salonu na Salon Artystów Francuskich i Salon Société Nationale des Beaux-Arts pod przewodnictwem Ernesta Meissoniera opowiedział Wojciechowi czeski malarz zamieszkały w Paryżu, Vaclav Brožik (1851-1901), autor scen historycznych, rodzajowych i pejzaży, zięć renomowanego paryskiego marszanda obrazów Sedelmeyera. Na Salonie Société Nationale des Beaux-Arts zniesiono nagrody i wyróżnienia. Por. także D. Lobstein, Les Salons au XIXe siècle. Paris capitale des arts, Editions de la Martinière, Paris 2006.

${ }^{38}$ W. Kossak, Listy do żony i przyjaciót (1883-1942), t. 1, s. 186.

39 Tamże, s. 166.

${ }^{40}$ Tamże, s. 177

${ }^{41}$ Tamże, s. 199.
} 
ślając, że polscy specjaliści w tej dziedzinie, a szczególnie Alfred Wierusz-Kowalski, Antoni Piotrowski czy on sam, są lepsi niż np. Edouard Détaille. Artysta portretował konie wyścigowe ze stajni Edmonda Blanca ${ }^{42}$, dla którego pracował także w Wielkiej Brytanii. Obok pozycji portrecisty ludzi chciał zdobyć reputację mistrza portretu końskiego, wysoko cenionego w środowisku hodowców koni wyścigowych. Marzył o przeniesieniu się do Paryża na stałe, snując nadzieje, że powiedzie mu się przynajmniej tak, jak Chełmońskiemu ${ }^{43}$. Planów tych jednak nie zrealizował.

W 1895 roku rozpoczął się w twórczości Kossaka trwający do 1902 roku okres berliński, naznaczony wielkimi sukcesami, zarówno artystycznymi, jak i społecznotowarzyskimi. Wydaje się jednak, że sława, pieniądze i awans społeczny zostały okupione wysoką ceną. Rola „nadwornego malarza” cesarza Wilhelma II nie zawsze była wdzięczna i łatwa, a nade wszystko była źle odbierana przez rodaków.

W czasie pobytu w Berlinie artysta podróżował, a także wystawiał poza tym miastem, m.in. w 1900 roku na Wystawie Światowej w Paryżu, podobnie jak inni malarze krakowscy, w pawilonie austriackim. Decyzja wystawienia Portretu cesarza Wilhelma II, pruskiego mocarza, niezbyt popularnego we Francji z racji żywej jeszcze w pamięci wojny francusko-pruskiej, mogła wydawać się zaskakująca, a jednak przyniosła artyście wyróżnienie. Rok później, w 1901, malarz odznaczony został krzyżem francuskiej Legii Honorowej $^{44}$. Uważał, że zawdzięczał ją przychylności markiza de Noailles ${ }^{45}$, ambasadora Francji w Berlinie, który docenił odpowiednie, ,profrancuskie” ujęcie drażliwych tematów historycznych, jakie Kossak podejmował w swojej twórczości:

Kompozycja Berezyny pojęta w duchu zaszczytnym dla Wielkiej Armii, bo złamanej tylko klimatem, była dopiero początkiem całej serii większych kompozycji batalistycznych, które już dla cesarza Wilhelma wykonałem. Prawie wszystkie tematy dane mi przez cesarza wyjęte były z wojen francusko-pruskich, a mianowicie z wojny siedmioletniej i z kampanii napoleońskich. Wszystkie te obrazy nosiły tak wyraźną cechę, po czyjej stronie są moje sympatie, że mi to wprawdzie bardzo delikatnie i łagodnie cesarzowa raz wytknęła, ale za to markiz de Noailles był ze mnie kontent ${ }^{46}$.

Krzyż Legii honorowej wręczony został artyście wraz z dyplomem przez hrabiego Szápáry ${ }^{47} \mathrm{w}$ ambasadzie austriackiej. Informację o nominacji Wojciecha podał paryski dziennik Gil Blas:

Malarz polski Albert de Kossak, który został mianowany rycerzem Legii Honorowej, urodził się w Paryżu. Syn słynnego akwarelisty Juliusza Kossaka i chrzestny syn Horace'go Verneta, jest szczególnie przywiązany do tematów celebrujących epopeję napoleońską. Jego płótna, malowane $\mathrm{z}$ niebywałą werwą, są wysoce cenione przez cesarza

${ }^{42}$ Edmond Blanc (1956-1920), syn wielkiego przedsiębiorcy Françoisa Blanca, dysponujący wielką fortuną francuski hodowca koni wyścigowych, założyciel stadnin; zajmował się także polityką.

${ }^{43}$ W. Kossak, Listy do żony i przyjaciót (1883-1942), t. 1, s. 172.

${ }^{44} \mathrm{~W}$ archiwach Orderu Legii Honorowej jest informacja, że Albert de Kossak, artysta malarz, został mianowany rycerzem Legii Honorowej jako obcokrajowiec (poddany austriacki) dekretem z 21 lipca 1901 r. Email Laurence Wodey, Service des décorations, Grande Chancellerie de la Légion d'Honneur, do Autorki z 30 marca 2018 r.

${ }^{45}$ W. Kossak, Wspomnienia, s. 111-112. Emmanuel Henri de Noailles (1830-1909), dyplomata francuski, ożeniony z Polką Eleonorą z Lachmanów $1^{\circ}$ voto Świeykowską (1837-1892). Markiz de Noailles był autorem szeregu esejów na temat Polski: La Pologne et ses frontières (1863), La Poésie polonaise (1866), Henri de Valois et la Pologne en 1572 (1867).

${ }^{46}$ W. Kossak, Wspomnienia, s. 112.

${ }^{47}$ Hrabia Frigyes Szapáry (1869-1935) był austro-węgierskim dyplomatą. 
Wilhelma II, którego Kossak wykonał znakomity portret konny. Portret ten odniósł wielki sukces na Wystawie w 1900 roku.

Prasa francuska ${ }^{48}$ wspomniała również, zapewne ze względu na podjętą po raz kolejny tematykę napoleońską, o jego panoramie Bitwa pod piramidami (1900-1901), cieszącej się w Warszawie wielkim powodzeniem. Namalowana wspólnie z Michałem Wywiórskim (i innymi) stanowiła ona swoistą kontynuację wykonanej wspólnie m.in. z Julianem Fałatem Berezyny (1894-1896). Artysta miał w planie namalowanie, również z Wywiórskim, panoramy Somosierra. Obaj artyści udali się w 1900 roku do Hiszpanii w celu dokładnego zapoznania się z topografią pola bitwy i wykonania szkiców. W drodze do i z Hiszpanii przejeżdżali przez Paryż, gdzie odwiedzili innego polskiego malarza batalistę, Jana Rosena. Wojciech studiował mundury w Muzeum Armii, a także konsultował się ze słynnym z wątków napoleońskich malarzem Edouardem Détaille'em. Projekt nie doczekał się jednak realizacji, gdyż gubernator Warszawy nie wyraził zgody na wystawienie panoramy.

Kolejnym paryskim epizodem było pokazanie na Salonie Artystów Francuskich Portretu amazonki ${ }^{49} \mathrm{~W} 1914$ roku. W tym samym czasie paryski Le Temps ${ }^{50}$ opublikował poświęcony polskiemu artyście długi Lettre d'Allemagne (List z Niemiec). Jego autor informował publiczność paryską o ukazaniu się Wspomnień Kossaka po niemiec$\mathrm{ku}$, cytując z nich obszerne fragmenty, w szczególności dotyczące berlińskiego życia dworskiego oraz przyczyn, dla których artysta opuścił stolicę Prus. Ciekawostką jest także, że w czasie pierwszej wojny światowej nazwisko Kossaka zacytowano w tajnej gazetce „Bulletin périodique de la presse polonaise" ${ }^{\text {, }}$, publikowanej jako informator wewnętrzny francuskiego Ministerstwa Wojny. Donosiła ona, za „Głosem Narodu” z 13 marca 1917 roku, że Kossak miał opracować wzór nowych mundurów wojskowych.

Już po odzyskaniu przez Polskę niepodległości Wojciech uczestniczył w wystawach o charakterze narodowym: sztuki polskiej w 1921 roku, gdzie obecny był tylko jeden jego obraz, Rok $1813^{52}$, oraz na wystawie France-Pologne w 1924 roku $^{53}$.

Kolejny dłuższy pobyt Kossaka w stolicy Francji miał miejsce w latach 20. XX wieku, w związku z realizacją portretu marszałka Focha. Ferdynand Foch odegrał wybitną rolę w czasie pierwszej wojny światowej jako dowódca wojskowy. W maju 1917 roku objął stanowisko szefa francuskiego Sztabu Generalnego. W styczniu 1918 roku przejął także funkcję przewodniczącego Rady Wojennej Sprzymierzonych, wreszcie został mianowany naczelnym wodzem Sił Alianckich. Dzięki przeprowadzonej przez niego udanej kontrofensywie nad Sommą we wrześniu 1918 roku wojska niemieckie zostały ostatecznie pokonane. W tym samym roku Foch został mianowany marszałkiem Francji, rok później marszałkiem polowym Wielkiej Brytanii, a w 1923 roku, przy okazji wizyty w Polsce, marszałkiem Polski. Wtedy to Rada miasta Warszawy

${ }^{48}$ Gil Blas nr 7937 z 11 sierpnia 1901 r., s. 1.

${ }^{49}$ Explication des ouvrages de peinture et dessins, sculpture, architecture et gravure et lithographie des artistes vivants exposés au Palais des Champs-Elysées, Paris 1914, s. 108, Portrait d'amazone, nr 1134.

${ }^{50}$ P. Comert, Lettre d'Allemagne, Le Temps nr 19274 z 13 kwietnia 1914 r., s. 2.

${ }^{51}$ Bulletin périodique de la presse polonaise (du 5 au 24 mars 1917), 11 kwietnia 1917 r., s. 4.

${ }^{52}$ Catalogue de l'exposition d'art polonais au Salon de la Société Nationale des Beaux-Arts, Paris, 13 avril-30 juin 1921, s. 11; nr 75, L'année 1813 (Rok 1813).

${ }^{53}$ Artistes polonais, Comoedia z 12 maja 1924 r., s. 2. Na wystawie pod patronatem ambasadora Chłapowskiego Kossak wystawił Portret marszałka Focha. 
zamówiła u Kossaka portret słynnego wodza ${ }^{54}$. Obraz miał być ofiarowany portretowanemu zamiast „kolejnej szabli czy buławy”, jako wyraz wdzięczności narodu polskiego. Nic nie wiadomo na temat ewentualnego spotkania Focha z Kossakiem w Polsce, wiemy jednak, że świeżo mianowany marszałek zobaczył we Lwowie Panorame ractawicka $^{55}$ autorstwa Wojciecha Kossaka, Jana Styki i innych.

W celu realizacji portretu Focha Kossak udał się do Paryża w sierpniu 1923 roku. Oficjalny charakter zamówienia zapewnił malarzowi wielką życzliwość i pomoc polskiego poselstwa, które nagłaśniało planowane przedsięwzięcie, np. rozsyłając o nim komunikaty prasowe. Udzieliło mu także jednej z sal recepcyjnych w swojej siedzibie przy ulicy Marignan na zaimprowizowaną pracownię. Jak przystało na prawdziwego dyplomatę kulturalnego, Kossak poprosił w poselstwie o instrukcje, w jaki sposób rozmawiać z marszałkiem o Polsce.

Ważnym argumentem za tym, żeby Foch w ogóle zgodził się na wykonanie portretu, było to, że Kossak sportretował wcześniej innego bohatera pierwszej wojny światowej, amerykańskiego generała Johna Pershinga ${ }^{56}$. Zasadniczy kształt kompozycji i jej szczegóły zostały omówione i ustalone $\mathrm{z}$ portretowanym ${ }^{57}$. Wbrew oczekiwaniom i zapowiedziom prasy francuskiej ${ }^{58}$ - Kossak był przecież mistrzem portretów konnych - Foch zdecydował się na portret w całej postaci, na stojąco, na tle pejzażu. Postanowił przyjąć wysoce symboliczną pozę zwycięskiego wodza, tę samą, jaką przybrał w lesie Senlis, kiedy przybyła do niego delegacja niemiecka, by negocjować zawieszenie broni: wyprostowany jak struna, z rękoma założonymi do tyłu.

Ponieważ marszałek miał powrócić do Paryża $\mathrm{z}$ wakacji dopiero w październiku, zdecydowano, że obraz, przynajmniej częściowo, będzie malowany w jego letniej rezydencji Troisfontaines w Bretanii, w pobliżu Morlaix. Dla Kossaka wyjazd do Bretanii był atrakcyjny. Choć urodzony we Francji, to - jak sam podkreślał - nie znał zupełnie Bretanii, regionu o swoistej, fascynującej historii i odrębności, podkreślanej na co dzień przez jej mieszkańców, noszących tradycyjne lokalne ludowe stroje i posługujących się własnym językiem. Bretania stała się modna jako cel wyjazdów artystycznych dopiero kilka lat po ukończeniu przez Wojciecha studiów we Francji, pod koniec lat 80. XIX wieku, za sprawą Paula Gauguina. W środowisku polskim modę tę rozpropagował Władysław Ślewiński, uczeń Gauguina. Dziki, dramatyczny pejzaż bretoński, a także potęga oceanu, jego fal i pływów, wywarły na Kossaku wielkie wrażenie. Fakt zamieszkiwania u swojego czcigodnego modela i uczestniczenia w jego codziennym życiu miał wpływ na efekt końcowy portretu. Przy bliższym poznaniu malarz nabrał do swego modela jeszcze większego szacunku, docenił jego głęboką religijność, zapoznał się z jego poglądami

${ }^{54}$ W. Kossak, Wspomnienia, t. 1-2, opracował, wstępem i przypisami opatrzył K. Olszański, Warszawa 1971, s. 322 i n. Okoliczności powstania portretu są przez artystę dokładnie opisane zarówno we Wspomnieniach, jak i na bieżąco, w listach, jakie wysyłał regularnie do żony.

${ }^{55}$ Lucienne Michou, Le Maréchal Foch inspectant les opérations sur le front de l'ouest en 1918. Commentaire historique et artistique d'un tableau de Wojciech Kossak, Bulletin de la Société académique des Hautes-Pyrénées 1988-1990, s. 194.

${ }^{56}$ W. Kossak, Portret generała Johna Pershinga, West Point Museum (inna wersja w Muzeum Polskim w Chicago). W swoich Wspomnieniach (1971), s. 327, Kossak pozwolił sobie na dość szczegółowe porównanie obu dowódców, z którego Foch w oczach zakochanego we Francji Kossaka wychodził zdecydowanie zwycięsko.

${ }^{57}$ Tenże, Listy do żony i przyjaciót (1883-1942), t. 2, s. 307.

${ }^{58}$ Le Maréchal Foch portraituré par un peintre polonais, La Lanterne nr 16835 z 4 września 1923 r., s. 2. Jak widać, informacje prasowe nie były ściśłe. Tę samą informację podał także L’Homme libre nr 2598 z 4 września 1923 r., s. 3. 
politycznymi, m.in. na temat Polski i jej konfiguracji politycznej. Poznał też rodzinę marszałka, poważnie dotkniętą i uszczuploną przez wojnę ${ }^{59}$. Kossak z kolei zaskarbił sobie względy Focha dzięki swojej gruntownej znajomości epopei napoleońskiej oraz admiracji, jaką żywił dla cesarza Francuzów.

Portret Focha przedstawia marszałka, stojącego na pierwszym planie, z rękami założonymi do tyłu, obserwującego niewidoczną dla widza bitwę, która rozgrywa się $\mathrm{w}$ oddali. Jedna $\mathrm{z}$ zaproponowanych interpretacji ${ }^{60}$ dzieła zwraca uwagę na to, że malarz zrezygnował ze swoich mistrzowsko opanowanych motywów — bitewnego zgiełku i wrzawy, skłębionych ciał żołnierzy i koni, krwawych odblasków płomieni wybuchów. Skupił się natomiast na portrecie psychologicznym naczelnego wodza wojsk alianckich, którego trafne decyzje i rozkazy doprowadziły do wycofania się nieprzyjaciela i ostatecznej wygranej. Artysta podkreślił jego rangę, plasując go na pierwszym planie i wysuwając do przodu i do góry w stosunku do otaczającej go eskorty wojskowej. Zastosował układ piramidalny grupy postaci, podkreślający pozycję głównego bohatera. Stojący za nim pozostali protagoniści wpisują się w trójkąt, którego wierzchołek stanowi górna krawędź kepi marszałka. Są to: kapitan Jean de Mierry, adiutant Focha, zajęty porównywaniem przebiegu bitwy z trzymanymi w ręku jej planami, i stojący obok kapitana generał Pierre-Henri Desticker, zastępca szefa sztabu sił alianckich, obserwujący, podobnie jak marszałek, przebieg sytuacji na horyzoncie. Tak dokładne sportretowanie członków sztabu miało na celu podkreślenie ich roli w osiągnięciu zwycięstwa. Na trzecim planie rozpoznać można adiutanta Pieri, dzierżącego proporczyk głównodowodzącego. Chociaż portret Focha nie jest portretem konnym, to przecież w obrazie mistrza celującego w malarstwie koni nie mogło ich zabraknąć. Artysta umieścił je w głębi kompozycji. Marszałek przedstawiony jest na tle zdewastowanego wojną pejzażu, zrytmizowanego nagimi kikutami postrzelanych, opalonych, poranionych drzew. Studia plenerowe wykonał Kossak w okolicach Péronne, gdzie jeszcze pięć lat po wojnie ślady zniszczeń i dewastacji były wyraźnie widoczne.

Uroczyste wręczenie obrazu Kossaka marszałkowi odbyło się 22 stycznia 1924 roku w polskim poselstwie, w obecności prezydenta Francji Alexandre'a Milleranda, premiera Raymonda Poincaré ${ }^{61}$, prezydenta Warszawy Ignacego Balińskiego, księcia Adama Ludwika Czartoryskiego ${ }^{62}$ i polskich dyplomatów. Obraz robił wrażenie nie tylko z powodu mistrzostwa wykonania, ale także imponujących wymiarów: $205 \times 245$ $\mathrm{cm}$. Na ramie zamocowano tabliczkę z bardzo skromnym, acz wymownym tekstem: „La Pologne reconnaissante” (Wdzięczna Polska) ${ }^{63}$. Na Salonie Artystów Francuskich

\footnotetext{
${ }^{59} \mathrm{Na}$ froncie Foch stracił jednego z zięciów oraz jedynego syna.

${ }^{60}$ L. Michou, Le Maréchal Foch inspectant, s. 198-199.

${ }^{61}$ Fotografia dokumentująca to wydarzenie znajduje się w zbiorach Bibliothèque nationale de France: 23/1/24, le comte Zamoisky [i.e. Zamoyski] remet au maréchal Foch le tableau de M. Kossak [à la légation de Pologne, rue Marignan] : [photographie de presse] / [Agence Rol] http://catalogue.bnf.fr/ark:/12148/cb45001628f [dostęp: 15 grudnia 2017].

62 Adam Ludwik Czartoryski (1872 Paryż - 1937 Warszawa), książę, arystokrata, mecenas sztuki, I Ordynat na Sieniawie, syn Władysława Czartoryskiego i Małgorzaty Orleańskiej; aktywny działacz wśród emigracji polskiej w Paryżu; prezes komitetu wręczenia portretu Fochowi.

${ }^{63}$ Po zaprezentowaniu obrazu na Salonie Artystów Francuskich w 1924 r. Foch umieścił go na honorowym miejscu w wielkim salonie pałacu księcia de Sens - swojej paryskiej rezydencji. Po jego śmierci wdowa przekazała go jako depozyt do Muzeum Armii w Pałacu Inwalidów. Od 1951 r. jest jedną z najważniejszych pamiątek po wielkim Francuzie wystawioną w jego domu rodzinnym w Tarbes, otwartym dla publiczności jako muzeum z okazji 100-lecia jego urodzin.
} 
w 1924 roku obraz zawisł w sali honorowej, wraz z dwiema innymi pracami artysty. Kossak wiązał z tą ekspozycją wielkie nadzieje:

Wczoraj na wernisażu Foch kochany przedstawił mnie Poicarému, we wszystkich dziennikach już piszą. Przywiozę ci to wszystko, naturalnie, że wystawa à l'Epatant [w Cercle d'Union Artistique - Koło Związku Artystycznego] co innego, a Salon, ce grand marché à toiles peintes [ten wielki rynek malowanych płócien], także co innego. Tam arystokracja sztuki i stylu, a tu demokracja ze wszystkimi kierunkami aż do najmodernistyczniejszych, więc jedne gazety, wierne wielkiej sztuce, obrzucają mnie kwiatami, a radykalne pomijają milczeniem. W każdym razie nie ma chyba dzisiaj nikogo inteligentnego, co by nie wiedział qui est Caussaque [kim jest Kossak] $]^{64}$.

Medalu jednak nie dostał i tym razem:

Medale rozdali, ale cudzoziemcom nic. Mało mnie to obeszło, bo to tutaj najmniejszego nie robi wrażenia. Opinia publiczna nie ulega wpływom żadnym, a to są skutki reklamowania rozmaitych futurystów i kubistów przez prase stronniczą. Toteż straciła i ona, i medale kredyt kompletnie. Trzeba widzieć jakie ohydy ont été recompensés [były nagrodzone $]^{65}$.

Także nadzieje na odznaczenie komandorią Legii Honorowej spełzły na niczym ${ }^{66}$. Artysta liczył na niezwykły wpływ tego portretu na jego karierę. Pisał do żony: „To nieśmiertelność ten mój Foch". W przechodzeniu do nieśmiertelności miały być pomocne m.in. publikacje prasowe. Malarz przyjmował dziennikarzy, instruował ich, co i jak mają o tym dziele pisać, udzielał wywiadów ${ }^{67}$. Oczywiście, spodziewał się także licznych zamówień i sukcesu finansowego jako logicznego następstwa sławy i rozgłosu. Żonie donosił, że rozgłos, jaki zyskał, był kolosalny: „Jeden entuzjazm, najmniejszej krytyki, sukces niekłamany, no taki, że od trzech dni we wszystkich teatrach i kinach podczas antraktów ukazuje się na kurtynie ekran, a na nim mój obraz z odpowiednią legendą" ${ }^{68}$. Jeszcze dwa tygodnie później pisał: „[...] moja sztuka wywołuje tutaj entuzjazm szalony, że roi się w tej Sali [w poselstwie — E. B.], że ambasady angielska, amerykańska przychodzą..." ${ }^{\text {69 }}$.

Synonimem wielkiego sukcesu było dla Kossaka także członkostwo w Cercle d'Union Artistique (Koło Związku Artystycznego), zwanym także Cercle de l'Epatant. Założone w 1860 roku, znane także jako Cercle des Mirlitons (Koło Fujarek), było jednym z trzech bardziej prestiżowych i elitarnych klubów męskich w Paryżu, o bardzo wysokich składkach członkowskich. Patronat nad Kołem jeszcze w latach 90. XIX wieku sprawowali władcy i arystokraci europejscy ${ }^{70}$. Trudno się więc dziwić, że Kossak, aspirujący do wyższych sfer, był przynależnością do Cercle, do którego, jak mocno podkreślał, należeli tylko „najwięksi” malarze (których dziś nazwać można salono-

${ }^{64}$ W. Kossak, Listy do żony i przyjaciót (1883-1942), t. 2, s. 351. Artysta specjalnie używa tutaj sfrancuszczonej transkrypcji swojego nazwiska „Caussaque”, jaką można było znaleźć w niektórych artykułach w prasie francuskiej.

${ }^{65}$ Tamże, s. 353.

${ }^{66}$ Tamże, s. 327

${ }^{67}$ Tamże, s. 328.

${ }^{68}$ Tamże, s. 328

${ }^{69}$ Tamże, s. 313-314.

70 O. Tolède-Léon, Le Salon de la Société Nationale des Beaux-Arts comme lieu d'épanouissement du mécénat privé dans les années 1890, [w:] Ce Salon à quoi tout se ramène. Le Salon de peinture et de sculpture, 1791-1890, James Kernes et Pierre Vaisse, Peter Lang, 2009, s. 112. 
wymi): John Singer Sargent, Joaquín Sorolla y Bastida, Philip de László, mile połechtany. Jego członkami wprowadzającymi byli sam Foch oraz poseł RP w Paryżu, hrabia Maurycy Zamoyski. W przyjęciu pomogli mu również francuscy koledzy po pędzlu: Jean Béraud, Henri Gervex i Albert Besnard, znani portreciści międzynarodowej paryskiej socjety i autorzy scen z życia wyższych sfer. Cercle de l'Epatant urządzał doroczne wystawy w lutym lub marcu, gdzie każdy z członków mógł wystawić po dwie prace. Kossak był niezwykle dumny z tego, że do tej pory żaden inny polski malarz (w szczególności Jan Styka, z którym był na ścieżce wojennej!) nie był zaproszony do pokazania tam swoich prac nawet jako gość, a co dopiero jako członek. Jak z dumą donosił żonie, jego prace Portret gen. Adriana Cartona de Wiarta i Szkic do portretu amazonki Lubomirskiej zostały tam ocenione bardzo pozytywnie: „Zdobyłem, Momo drogie, Paryż, bez blagi, bez reklamy, uczciwą pracą, i talentem po Preziu drogim"71.

Nie doszło natomiast do wielkiej wystawy indywidualnej, jaką Kossak planował pod patronatem żony polskiego posła Maurycego Zamoyskiego. W styczniu 1924 roku Zamoyski opuścił Paryż, by objąć tekę ministra spraw zagranicznych. Nie zrealizował także planowanej na styczeń 1925 roku wystawy w paryskiej Galerie Charpentier ${ }^{72}$. Pokazał natomiast swoje prace raz jeszcze na Salonie Artystów Francuskich, a obracanie się $w$ towarzystwie polskiej arystokracji w Paryżu zapewniało mu zamówienia portretowe.

Jak widać, na różnych etapach swego życia i kariery Kossak był żywo związany $\mathrm{z}$ francuską stolicą. Pomimo niezwykłego powodzenia, jakim cieszyło się jego malarstwo, i wzięciu, jakie miał sam malarz w rozmaitych, w tym wyższych sferach społecznych, listy do żony świadczą jednak o tym, że jego największym pragnieniem było podbicie Paryża. W różnych okresach celowi temu miały służyć rozmaite środki, z całą pewnością kontakty towarzyskie, w szczególności w kręgach dyplomatycznych i arystokratycznych. Przyjmował prestiżowe zamówienia, które wykonywał gratisowo, byle tylko móc je wykorzystać do celów reklamowych. Przykładem paryskim może być Portret aktorki panny D., a także Focha. Skłonienie marszałka do wspólnego sygnowania studiów przygotowawczych do portretu świadczy o znakomitym zrozumieniu mechanizmów rynkowych. Kossak wiedział, jak zabiegać o odpowiednie kontakty towarzyskie i zawodowe, bywał w odpowiednich miejscach w odpowiednim czasie, starał się o to, by jego tymczasowa pracownia była korzystnie zlokalizowana (np. w sali recepcyjnej polskiego poselstwa w Paryżu) i miała odpowiedni standing, tak żeby można tam było zaprosić elitarne towarzystwo, spośród którego mieli się rekrutować jego potencjalni klienci. Miał też świetne rozeznanie, gdzie i jak należy wystawiać. Stosował także nowoczesne metody reklamowe. Chętnie posługiwał się fotografią, nie tylko po to, żeby pomóc sobie w malowaniu portretów, zarówno ludzi, jak i koni. Już w latach 1920 posiadał to, co dziś nazwalibyśmy „bookiem” czy „portfolio”, czyli album z fotografiami swoich prac, które dla potencjalnych klientów były „witryną”, prezentującą najlepsze osiągnięcia artysty, a równocześnie rodzajem katalogu, z którego klient być może nie wybierał bezpośrednio pozy, w której chciał być sportretowany, ale styl i atmosferę przyszłego portretu. Była to swoista wizualizacja avant la lettre. W 1890 roku nie zawahał się wywołać skandalu na paryskim Salonie i potrafił go wykorzystać. Wtedy też prawdopodobnie zrozumiał potęgę prasy i starał się, by odpowiednie wia-

\footnotetext{
${ }^{71}$ W. Kossak, Listy do żony i przyjaciól (1883-1942), t. 2, s. 339.

${ }^{72}$ Tamże, s. 350.
} 
domości dotarły do właściwych tytułów, zwłaszcza polskich, nie stroniąc od autoreklamy $^{73}$.

Wydawać by się mogło, że artysta osiągnął swój cel, skoro pisał: „Jednym słowem wypłynąłem na pełne morze i nareszcie marzenie całego mojego życia się krystalizuje. Mieć sukces w Paryżu!"’74. Te słowa 67-letniego malarza są zadziwiające, zwłaszcza że, kierując w pełni świadomie i celowo swoją karierą artystyczną, podsumowywał ją następująco: „I dziwna rzecz wszystko się robi samo, wszystko się składa jakby naumyślnie. Jakiś niewidzialny, a genialny manager kieruje moją barką. Manio, nic nie przesadzam, wariują Francuzi za moją sztuką"75. I tu warto przypomnieć sobie, co pisała mająca już za sobą sukcesy międzynarodowe Olga Boznańska do swego ojca niemal 30 lat wcześniej, kiedy w 1896 roku jej obrazy zostały przyjęte na paryski Salon: „Stało się to, czego najwięcej pragnęłam w życiu, wystawiłam prace swoje bez protekcji na Polu Marsowym. Mogę jeszcze kiedyś o wiele lepiej malować niż dziś, większy honor mnie już nigdy spotkać nie może," ${ }^{, 16}$. Chociaż wypowiedź Boznańskiej i Kossaka dzieliło tyle lat, to mit Paryża nadal obowiązywał.

Nie jest natomiast pewne, czy Kossak rzeczywiście właściwie odczytywał sygnały percepcji jego prac w Paryżu, czy też oddawał się, jak w przytłaczającej większości jego listów do żony, myśleniu życzeniowemu. $Z$ pewnością ignorował i bagatelizował uwagi krytyczne, jakie ukazywały się w bardziej postępowej — w sensie artystycznym - prasie. Nie należał on, podobnie jak jego francuscy malarscy idole, do ówczesnej awangardy, zwłaszcza w latach 20. XX wieku. Dziś natomiast jest już pora, by jego sztukę, podobnie jak jego mistrza Bonnata i innych malarzy salonowo-akademickich, odczytywać na nowo.

\section{LITERATURA}

About E., Nos artistes au Salon de 1857, Paris 1858.

Archives de l'Ecole nationale supérieure des beaux-arts (AJ $\left.J^{52} 1-1415\right)$. Inventaire par Brigitte Labat-Poussin avec la collab. de Caroline Obert, Table générale des dossiers du personnel et des élèves, Centre historique des Archives nationales: la Documentation française, Paris 1998.

Artistes polonais, Comoedia z 12 maja 1924.

Bulletin périodique de la presse polonaise (du 5 au 24 mars 1917), 11 kwietnia 1917.

Catalogue de l'exposition d'art polonais au Salon de la Société Nationale des Beaux-Arts, Paris, 13 avril-30 juin 1921.

Duret T., Les Peintres impressionnistes, Paris 1878.

Explication des ouvrages de peinture et dessins, sculpture, architecture et gravure et lithographie des artistes vivants exposés au Palais des Champs-Elysées, Paris: 1857 nr 1486; 1859 nr 1678; $1878 \mathrm{nr} 1265,1879 \mathrm{nr} 1699 ; 1880 \mathrm{nr} 2018 ; 1914$.

${ }^{73}$ Po wizycie u Focha w Bretanii wysłał żonie jej opis z prośbą o przekazanie go do redakcji „Rzeczpospolitej” lub innej gazety. Jednak natychmiast po pojawieniu się oficjalnego opisu autorstwa Polskiej Agencji Telegraficznej artysta, wiedząc, że autoreklama jest gorsza niż reklama, gwałtownie tę akcję powstrzymał. Kilka lat później opublikował jednak swój tekst w IKC nr 115 z 28 kwietnia 1929 r. pod tytułem Moich kilka dni w Troisfontaines, oraz w Naokoło Świata $1933 \mathrm{nr} 105$ pod tytułem Foch i Pershing.

${ }^{74}$ W. Kossak, Listy do żony i przyjaciót (1883-1942), t. 2, s. 315.

${ }^{75}$ Tamże.

${ }^{76}$ H. Blum, Olga Boznańska. Zarys życia i twórczości, Kraków 1964, s. 38. 
Exposition Universelle de 1867 à Paris Catalogue général publié par la Commission Impériale le livraison: oeuvres d'art Groupe I Classes, 1 à 5, Paris-London 1967.

Guinard P., Les thèmes polonais dans l'art français du XIXe siècle, [w:] C. FilipowiczOsieczkowska, P. David, P. Guinard, A.-J. Lauterbach, W. Tatarkiewicz, Art polonais art français: Études d'influences, Paris 1939.

http://catalogue.bnf.fr/ark:/12148/cb45001628f

Hugo V., Euvres complètes, t. 25, Paris 1913.

Kossak W., Listy do żony i przyjaciót (1883-1942), t. 1-2, oprac. K. Olszański, Kraków 1985.

Kossak W., Wspomnienia, Warszawa-Lublin-Łódź-Kraków 1913.

Kossak W., Wspomnienia, t. 1-2; oprac., wstępem i przypisami opatrzył K. Olszański, Warszawa 1971.

Kossakowie, przewodnik po wystawie, red. Z. Żygulski jun., Kraków 1986.

Kubaszewska H., Wojciech Kossak, [w:] Stownik artystów polskich $i$ w Polsce działajacych (zmarlych przed 1966 r.). Malarze, rzeźbiarze, graficy, t. IV: K1-La,Warszawa 1986.

L'Homme libre $1923 \mathrm{nr} 2598$.

La Lanterne 1923 nr 16835.

Le Temps 1914, nr 19274.

L'Intransigeant $1884 \mathrm{nr} 1625$.

Lobstein D., Les Salons au XIXe siècle. Paris capitale des arts, Paris 2006.

Michou L., Le Maréchal Foch inspectant les opérations sur le front de l'ouest en 1918. Commentaire historique et artistique d'un tableau de Wojciech Kossak, Bulletin de la Société académique des Hautes-Pyrénées 1988-1990.

Polonia. Des Polonais en France de 1830 à nos jours, red. J. Ponty, Paris 2011.

Réaux L., L'art français en Pologne au XIXe siècle, Revue des Études Slaves 1923 t. 3.

Saigne G., Léon Bonnat, le portraitiste de la IIIe République, Paris 2017.

Salon de 1890. Catalogue illustré. Peinture, sculpture/ publié sous la direction de F.-G. Dumas; L. Baschet, Paris 1890.

Tolède-Léon O., Le Salon de la Société Nationale des Beaux-Arts comme lieu d'épanouissement du mécénat privé dans les années 1890, [w:] Ce Salon à quoi tout se ramène. Le Salon de peinture et de sculpture, 1791-1890, James Kernes et Pierre Vaisse, Peter Lang, 2009

Vernet H., Alegoria Polski zwyciężonej albo Prometeusz polski, Paryż, ok. 1831.

\section{'TO SUCCEED IN PARIS!' THE KOSSAKS — FATHER AND SON — CONQUER PARIS}

Paris had attracted Poles since the end of the $17^{\text {th }}$ century, both for political and artistic reasons. Artists could get an education, develop their careers, and become famous. Juliusz Kossak arrived in Paris in 1855 and spent five years in the French capital, which greatly influenced his creative work. Wojciech Kossak was born in Paris, yet, having spent his childhood in Poland, he returned to the French capital to study art. Later, he visited Paris several times; during one of his visits he painted a portrait of Marshal Ferdinand Foch, the victorious leader who contributed to reestablishing peace after the First World War. For Wojciech Kossak, his success in the artistic milieu of Paris was the highlight of his artistic career, notwithstanding his success in the Motherland. The essay discusses the visits of Juliusz and Wojciech Kossak to the French capital. It pays particular attention to Wojciech Kossak's painting of Marshal Ferdinand Foch and the artist's attempts to conquer Paris, which he saw as a synonym of artistic success.

KEY WORDS: Juliusz Kossak (1824-1899), Wojciech Kossak (1856-1941), 19 ${ }^{\text {th }}$-century and $20^{\text {th }}$-century Polish painting, Polish artists in Paris, Polish artists abroad, Polish art abroad, Polish-French relations, Marshal Ferdynand Foch (1851-1929)

SŁOWA KLUCZOWE: Juliusz Kossak (1824-1899), Wojciech Kossak (1856-1941), malarstwo polskie XIX i XX wieku, artyści polscy w Paryżu, artyści polscy zagranicą, polska sztuka zagranicą, relacje polsko-francuskie, marszałek Ferdynand Foch (1851-1929) 